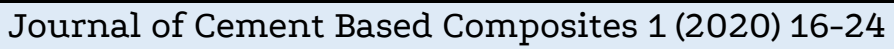 Cement Based Composites
}

www.acapublishing.com

Research Article

\section{Hybrid Fiber Reinforced Concrete with Pozzolanic Materials}

Saeid Golizadeh Fard

MSc. candidate, Department of Civil Engineering, Islamic Azad University, Arak branch, Iran

\section{Keywords}

Steel Fibers,

Micro Silica,

Compressive Strength,

Flexural Strength,

Tensile Strength

\begin{abstract}
This paper investigates the possibility of combining steel fibers with different weight percentages along with their functions in increasing compressive strength, indirect tensile strength and bending strength. It's been considered an important economic issue for a long time the ability to service and increase the load-bearing capacity of structural materials. Concrete as a widely used structural material is widely used today. Despite its remarkable properties including high ductility, high durability, longevity, availability and low cost, concrete is a brittle material and performs extremely poor under flexural and tensile loads. In general, the breakdown and destruction of concrete is strongly dependent on the formation of cracks and micro-cracks. As the loading increases, the micro-cracks interconnect and form cracks. In order to address this problem and to create homogeneous conditions, a series of thin filaments has been used throughout the concrete in recent decades; They are called fibers. Steel fiber is one of the most commonly used fibers in concrete. In this study, the compressive strength of concrete was investigated which in some specimens reinforced with steel and containing pozzolanic materials, the compressive strength of control samples increased with the use of fiber etc. In the present study, the flexural and tensile strength of steel fiber reinforced specimens were investigated. According to the results, flexural strength increases with increase in steel fibers. The designs contain 1\%, 1.5\% and $2 \%$ of the Dramix hooked steel fibers used in the research. By reinforcing the specimens with steel fibers, the behavior of tensile concrete is much more flexible than that of non-steel specimens.
\end{abstract}

\section{Introduction}

The concrete has advantages and disadvantages due to its structure, related to lower tensile and bending strength than compressive strength. This produces the fragile (softening) behavior of concrete, sudden failure and disintegration of the concrete structures. From the mid-18th century, steel bars have been used to improve the fragile behavior of concrete under tension. The accurate position of tensile strength has not been obvious in some cases and all steel bars cannot be spread in all given points. For this reason, the different kinds of fibers used as one of solutions are investigated to improve the fragile behavior of concrete and to decrease its permeability [1]. Steel fibers added to the concrete enhance the mechanical properties such as strength, ductility, durability, and performance under dynamic load and strike [2-3].

Due to the ability of the relevant ductility and high tensile strength, Steel fibers having high elastic modulus and fracture strain are considered as the most appropriate and cost-effective fibers in the different-looking forms (direct, tooth, hooked end) to improve the behavior of concrete [4]. There is not the accurate evidence when steel fibers have been utilized, but several individuals have used some distinct methods such as pieces of cords or metal cuts into concrete, entitled the methods to their own name [5]. In 1960s, the steel fiberreinforced concrete was first performed by Baston and Ramualdi in U.S. Then, the industrial uses of the steel fiber- reinforced concrete have been investigated [6]. Qureshi et al. (2008) explored the properties of high strength concrete with adding steel fibers. The results showed that tensile strength is linearly increased with adding steel fibers and the process will be rapider in the first seven days [7]. Kim et al. (2010) described correlation and dependence between tensile and bending behavior of cementitious composites. Two types of high-strength steel fibers (hooked and Torex) have been used in cementitious matrix with $8 \mathrm{MPa}$ compressive strength. Bending and tensile specimens reinforced with 1 fiber volume percent have been utilized to estimate the material behavior. Bending specimens have been prepared in three sizes: $50 * 25 * 300 \mathrm{~mm}, 100 * 100 * 300 \mathrm{~mm}$, and $150 * 150 * 450 \mathrm{~mm}$. the results conclude that specimens made through both hooked and Torex fibers demonstrate the hardening behavior of displacement. However, Torex fiber-reinforced specimens have higher bending strength [8]. Vandewalle (2008) examined Hybrid fiber- reinforced concrete. He used three steel fibers (very short fibers $6 \mathrm{~m}$ in length, short fiber $13 \mathrm{~mm}$ in length, and long hooked-end fiber $35 \mathrm{~mm}$ in length). In these tests, pillars were used $550 \mathrm{~mm}$ to $13 \mathrm{mmin}$ length and $150 \mathrm{~mm}$ in height. The used fiber volume has been 0 to 90 $\mathrm{kg}$ per $\mathrm{m} 3$, added to the concrete mixture in a distinct way and in mixed way including two or three fibers. The results of measuring the crack mouth opening displacement indicates that 3 and $13 \mathrm{~mm}$ fibers are very effective in places of micro crack opening. While $35 \mathrm{~mm}$ fibers provide a good ductility in the wide and big, micro cracks grow and join together and finally they connect to big cracks. Long hooked end fibers are very active to be connected to the crack [9]. Pul (2010) examined tensile strength, bending strength, and compressive strength to divide high strength- and performance - concrete and measured the relation between properties and compressive strength. The used specimens have different strength from 48 to $81 \mathrm{MPa}$ [10]. $\mathrm{XU}$ and Shi (2009) investigated the relation between mechanical properties of the typical concrete and fiber concrete. These fibers have 
consisted of Polypropylene, glass fibers, and steel fibers. And compressive strength, tensile strength to divide and bending strength have been considered as parameters expressing the mechanical properties [1]. Rodrigues et al. (2010) have studied the behavior of fiber-reinforced concrete pillars. There are four pillars in the study $0.25 * 0.25 \mathrm{~m}$ in dimensions and $3 \mathrm{~m}$ in height, having been reinforced through the distinct linear strap. The first pillar to third pillar include $38.8,27.24,16.56 \mathrm{~kg}$ steel fibres and $1.5 \mathrm{~kg} / \mathrm{m}$ Polypropylene fiber, respectively. The fourth pillar is lack of fiber. The results showed that Polypropylene and steel fibers used in the concrete improve the behavior of pillars in fire. Polypropylene fiber can control concrete delamination. Also, the pillar always need some steel bars for strength against fire. It is not a good way to replace steel bars with steel fibers in concrete against fire [11-12]. Nili and Afroughsabet (2010) researched the effect of pulverized silica and steel fibers on impact strength and mechanical properties of the concrete. the results showed that the added steel fibers improve tensile strength and bending strength. Also, steel fibers added to the specimens including pulverized silica enhance impact strength and ductility of the concrete considerably [13].

\section{Steel fiber- reinforced concrete}

Fiber concrete (steel fiber) consists of a concrete skeleton mixed into cement, stony materials, water and a percentage of short steel fiber randomly spread through mixture in the different direction, and steel fiber enhances the properties of concrete to a specific condition. Steel fiber-reinforced concrete is casted and compressed as a simple concrete. The mixture of steel fiber reinforced concrete is designated the same as simple concrete.it is important to consider how fibres are invariably spread, are avoided to be detached and to be balled, and an efficient mixture is produced to cast, compact, and finish concrete [1518].

\subsection{Objective of the study}

The present study is aimed at investigating the effect of fiber volume on strength parameters of steel fiber concrete and testing the amount of the different weight fiber concrete. Also, each of factors including strength and behavior have been studied here.

\subsection{Compressive strength}

in the study, compressive strength has been estimated in accordance with ASTMC 39 standard. According to the standard, loading speed must be constant. for this reason, cube specimens have been by size $150 * 150 * 150 \mathrm{~mm}$. to determine compressive strength, compression machines having ultimate capacity of 300 tons have been used.

\subsection{Indirect tensile test knows as the Brazilian test}

To test tensile strength, the cylindrical samples of steel fiber reinforced concrete have been evaluated through using splitting test of specimens (Brazilian test) and the results have been compared together and to specimen without fiber. 28-day tensile strength test has been measured on the basis of ASTM C96 standard. Cylindrical tests (Fig.2) used in the test have been 100*200 $\mathrm{mm}$ in dimensions. The number of three specimens located at each of the given levels has been made out of four volumes without fibers; $1 \%, 1.2 \%$, and $2 \%$. Rupture stress has been calculated in accordance with the following equation:

$F_{S P}=F_{C T}=\mathrm{T}=\frac{2 \times P \times 1000}{\Pi \times L \times D}$

$\mathrm{T}$ : rupture stress at $\mathrm{MPa}$

$\mathrm{P}$ : the maximum load of the machine at $\mathrm{KN}$

$\mathrm{L}$ : specimen length at $\mathrm{mm}$

$\mathrm{D}$ : specimen diameter at $\mathrm{mm}$

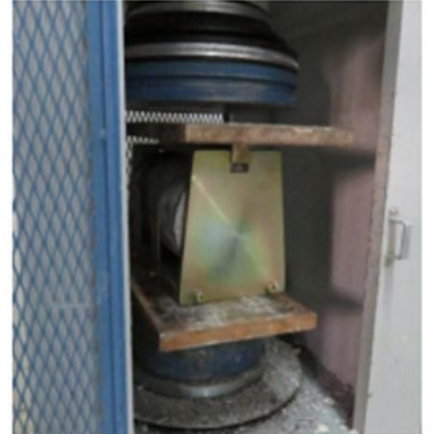

Fig.2- cylindrical specimen is testing tension through the gap method of specimen (Brazilian)

With ASTM C78 [14] standard, bending test is performed through fourpoint bending machine (fig.3). As the figure has shown, four-point test machine has been used to test bending. Bending strength of rectangular-cube specimens of steel fiber-reinforced concrete are compared together and to specimens without fiber. Rectangular- cube specimens are $100 * 100 * 500 \mathrm{~mm}$ in dimensions. The number of three specimens located at each of the given levels has been made out of four volumes without steel fibers; $1.5 \%, 2 \%$, and $2.5 \%$.

\subsection{CRACKING PATTERN}

To examine cracking pattern of the matrix tensile specimens reinforced with the different percentages of fibers, parameters such as the number of cracks, width of cracks, and their distance from each other are investigated. In cracking of the matrix specimens reinforced with fibers, it is true that the energy of material and their ductility are higher when the number of cracks and their distance from each other is more.

\section{The used material}

Quartz grains have maximally been used $5.0 \mathrm{~mm}$ in dimensions. The dimension of the grains used in the study are shown in table 1:

Table.1. Some properties of the quartz grains

Bulk dry specific gravity

Absorption, \%

Dry-rodded unit weight, $\mathrm{kg} / \mathrm{m}^{3}$

2.62

$\mathrm{lb} / \mathrm{ft}^{3}$

0.41

Sieve

106.2

\begin{tabular}{ll} 
Sieve & \\
$25.0 \mathrm{~mm}$ & $(1 \mathrm{in})$ \\
$19.0 \mathrm{~mm}$ & $(3 / 4 \mathrm{in})$ \\
$12.5 \mathrm{~mm}$ & $(1 / 2 \mathrm{in})$ \\
$9.5 \mathrm{~mm}$ & $(3 / 8 \mathrm{in})$ \\
$4.75 \mathrm{~mm}$ & $($ No. 4$)$ \\
\hline \multicolumn{3}{c}{ Fine aggregate } \\
\hline Bulk dry specific gravity \\
Absorption, \% \\
Fineness modulus \\
\hline \multicolumn{3}{c}{ Sieve } \\
$4.75 \mathrm{~mm}$ \\
$2.36 \mathrm{~mm}$ & (No. 4) \\
$1.18 \mathrm{~mm}$ & (No. 8) \\
$600 \mu \mathrm{m}$ & (No. 30) \\
$300 \mu \mathrm{m}$ & (No. 50) \\
$150 \mu \mathrm{m}$ & (No. 100) \\
$75 \mu \mathrm{m}$ & (No. 200)
\end{tabular}

Percent passing 100

75

50

25

284

The quality and requirements used in the steel fiber-reinforced concrete is similar to water used in the typical concrete. Water used in the study was provided with drinking water in Arak which is qualitatively acceptable. Concrete used to make all specimens are type 2 concrete from Delijan concrete factory. Micro silica (silica fume) grout and PCE super plasticizer used in the study have been from products of Vand chemical company. Hooked steel fibers and wavy steel fiber used in the study have been presented in table 2.Fig. 2 shows the test machine used in this research. In one of the plates on the upper part, there are two holes in the middle of the passage of the 
vacuum hose from the first hole. The load cell is inserted into the second hole, and four sets of studs on the four sides of the plate lift the plate using a welding crane. On the sides of the plates, three holes of the bolt are intended to be six in total, until the configuration shown in Fig. 2 is achieved. The reason for these six bolts is the installation of a top plate assembly, which, when tested with the crane, prevents these bolts from entering the axial load into the cylinder. Also, the fibers employed in the research consist of three types of hooked steel fiber. the characteristics of which are shown in Fig. 3.

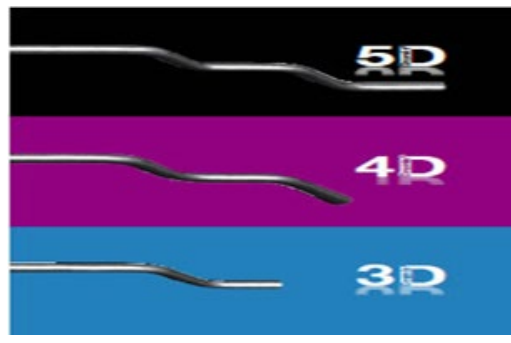

Fig.3. The fibers

Table. 2. Properties of the steel fibers

\begin{tabular}{|c|c|c|c|c|c|c|}
\hline $\begin{array}{l}\text { Elastic Modulus } \\
\qquad(\mathrm{GPa})\end{array}$ & $\begin{array}{l}\text { Tensile } \\
\text { Strength } \\
\text { (MPa) }\end{array}$ & $\begin{array}{l}\text { Special weight } \\
(\mathrm{kg} / \mathrm{m} 3)\end{array}$ & $\begin{array}{l}\text { Length } \\
(\mathrm{mm})\end{array}$ & $\begin{array}{l}\text { Diameter } \\
(\mathrm{mm})\end{array}$ & $\begin{array}{c}\text { Mechanical } \\
\text { Control }\end{array}$ & Name of the fiber \\
\hline 2100 & 1225 & 7850 & 60 & 0.75 & hooked & DRAMIX 3 D \\
\hline 2100 & 2300 & 7850 & 60 & 0.9 & Hooked & DRAMIX 5 D \\
\hline
\end{tabular}

\subsection{The plan of mixture}

The experimental work is aimed at obtaining the high-strength and efficient cementitious matrix and measuring the mechanical properties. The study has investigated how the different percentages of steel fibers have effect on specimens including micro silica (silica fume). To examine compressive strength, cylindrical specimens (fig.4) have been made $100 * 200 \mathrm{~mm}$ in dimensions. To examine bending strength, prismatic specimens have been $100 * 100 * 350 \mathrm{~mm}$ in dimensions. To examine tensile strength, cylindrical specimens have been made $100 * 200$ in dimensions. Water-cement ratio (w/c ratio) in steel fiber-reinforced concrete is lower than in rich concrete. According to way of composing the concrete, water-cement ratio is about 0.30-0.55. The study aims to compare the effect of steel fibres on the mechanical properties of steel fibre-reinforced concrete. in all plans of mixture, water-cement ratio and quartz grain-cement have been fixed, so they have been considered 0.30 and 1.58 , respectively.to provide the control plan, nine plans without fibre to fracture have been made in 3,7,28 days. To provide specimens reinforced with $1 \%$, $1.5 \%, 2 \%$ fibres (based on weight of cement), three specimens to fracture was made in 28 days old with $10 \%$ in cement-micro silica weight. To produce fibre specimens, the amount of super plasticizer is equal to $/ 6 \%$ by weight of total cement -silica fume ratio for all given plans. The procedure of mixture and the final plan of mixture from cement matrix have been presented in Table 3 and Table 4.

Table.3. The mix

\begin{tabular}{cl}
\hline Grain & $2 \mathrm{~min}$ \\
Cement & $2 \mathrm{~min}$ \\
Micro silica (silica fume) & $1 \mathrm{~min}$ \\
Super plasticizer+70\% water & $4 \mathrm{~min}$ \\
$30 \%$ rest water & $4 \mathrm{~min}$ \\
\hline
\end{tabular}

Table. 4- The final plan of mixture from cement matrix

\begin{tabular}{cccccc}
\hline $\begin{array}{c}\text { Cement } \\
\text { matrix }\end{array}$ & Cement & $\begin{array}{c}\text { Micro } \\
\text { silica }\end{array}$ & Grain & Water & $\begin{array}{c}\text { Super } \\
\text { plasticizer }\end{array}$ \\
$\begin{array}{c}\text { Weight } \\
\text { ratio }\end{array}$ & 1.00 & 0.10 & 1.58 & 0.35 & 0.006 \\
\end{tabular}
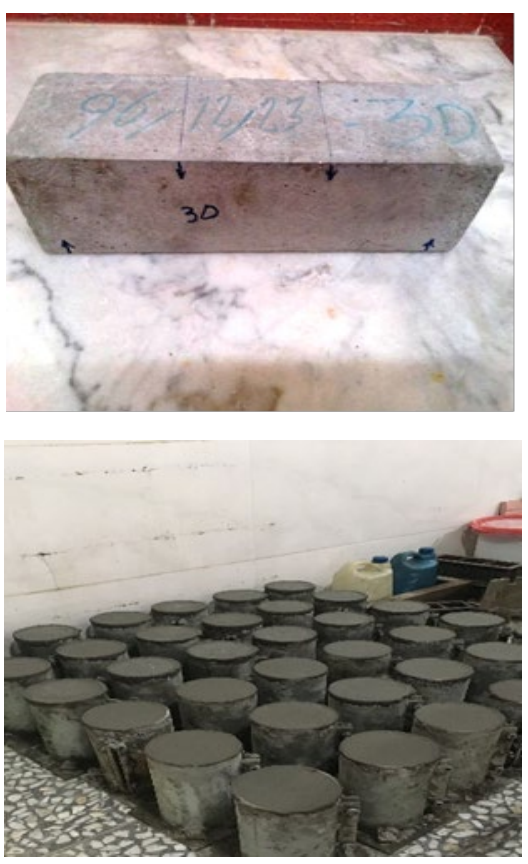

Fig.4. The samples

\section{Results}

To examine the effect of using steel fiber on compressive strength of steel fiber -reinforced concrete, graphs of compressive-strength changes in specimens reinforced with $1 \%, 1.5 \%, 2 \%$ fibers have been drawn in Fig. 5-7 for 28 days, respectively. 


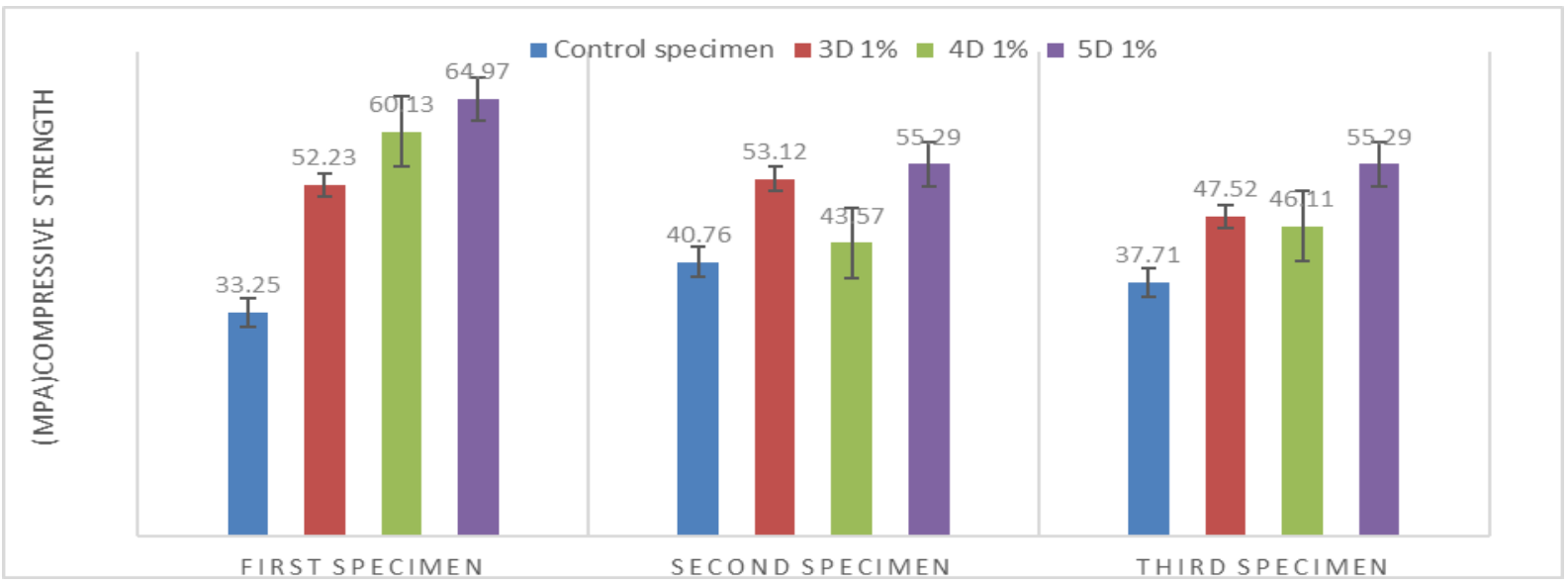

Fig.5. The effect of steel fiber volume on 28-day compressive strength of concrete reinforced with $1 \%$ steel fiber

The compressive strength of the specimens decreased with increasing amount of hooked steel fibers used in concrete. One possible reason is that increasing the amount of steel fibers, in addition to reducing the efficiency of the concrete, creates a gap between the concrete particles and decreases the integrity of the cement mortar. Also, the best amount of hooked steel fibers is $2 \%$ which controls the decreasing trend of compressive strength of concrete.

As the above graphs have showed, 28- day compressive strengths of the fracture specimens are close each other. In the condition, steel fibers cause to decrease long -time compressive strength of the concrete in some specimens. According to Fig. 10, not only the plan including 1.5 percentage of 4-D hooked steel fiber but also 28-day compressive strength have been enhanced in all specimens. According to the results, the highest 28-day compressive strength is related to specimens reinforced with 1 percentage of 5-D steel fiber (hooked steel fiber $\mathrm{L} / \mathrm{D}=65$ ), increased by $57.13 \%$. Also, the lowest compressive strength is related to $4-D$ hooked steel fiber $(L / D=65)$, decreased by $4.33 \%$.

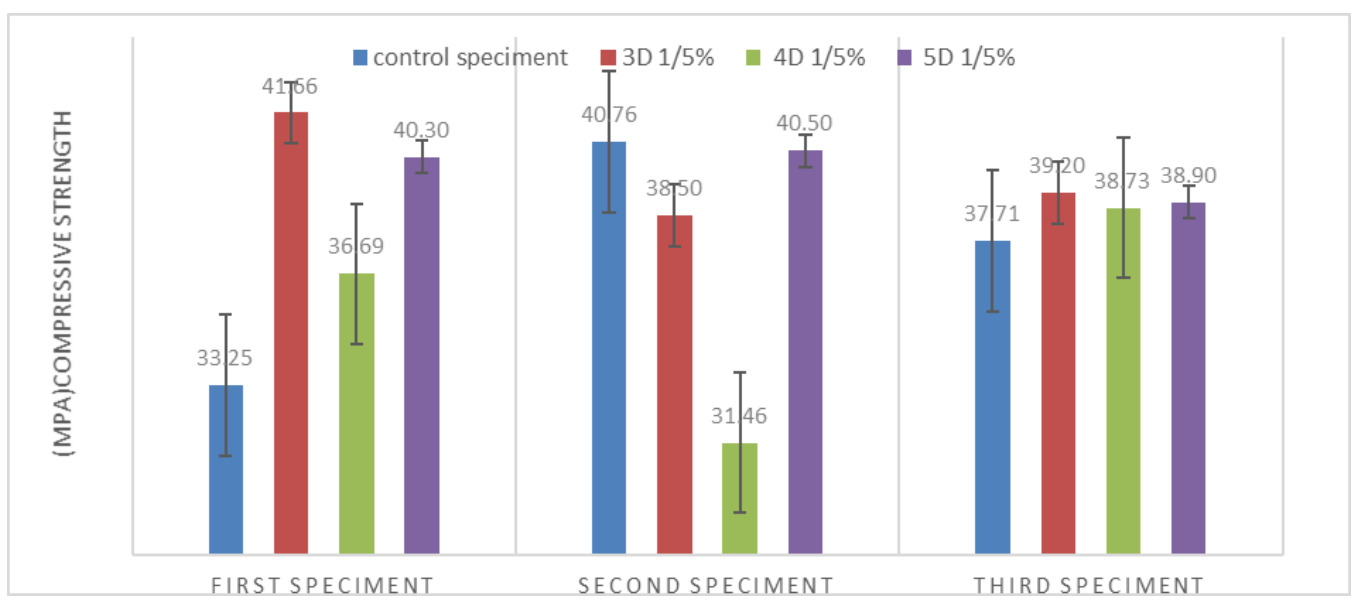

Fig.6. The effect of steel fiber volume on 28-day compressive strength of concrete reinforced with $1.5 \%$ steel fiber

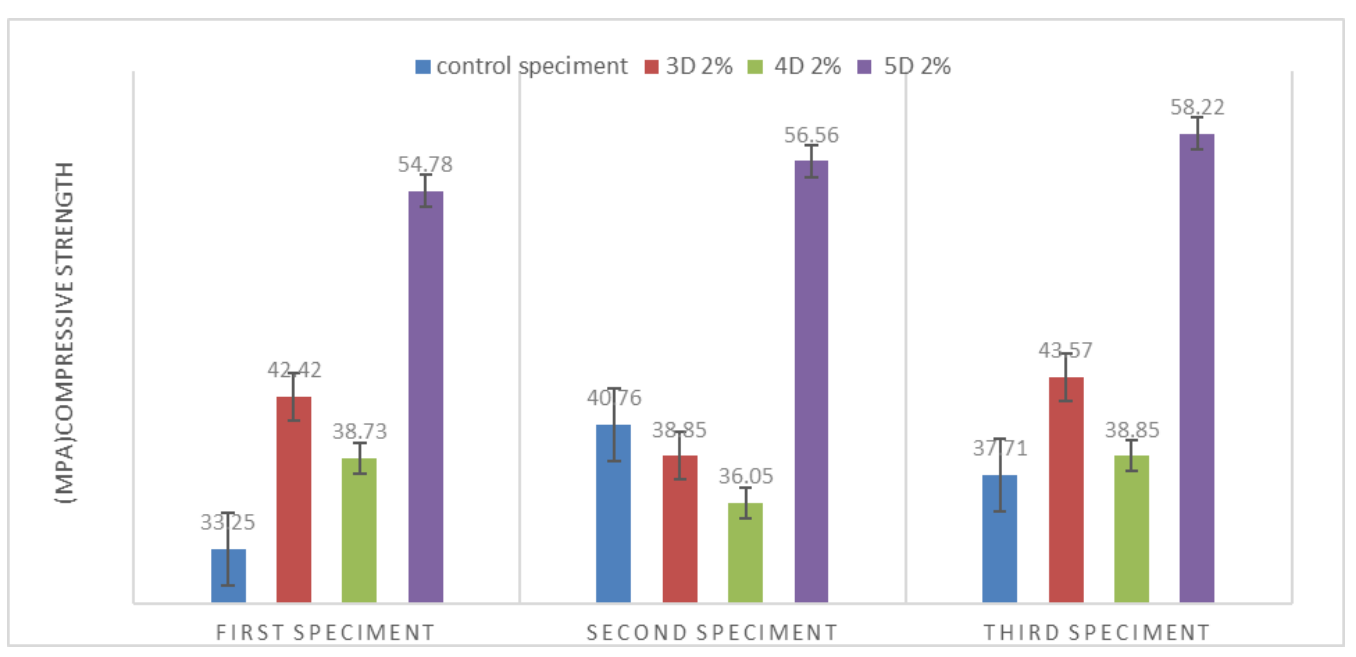

Fig 7. The effect of steel fiber volume on 28-day compressive strength of concrete reinforced with $2 \%$ steel fiber 


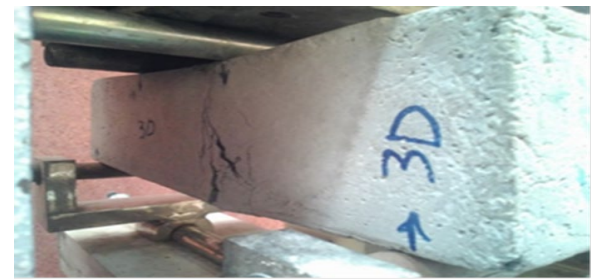

Fig.5- Four-point Flexural machine

To examine bending strength, specimens have been tested (fig.5) after 28 days. A support is placed at a distance of $15 \mathrm{~cm}$ from two heads of specimens. Thus, duration of the experiment is $450 \mathrm{~mm}$. tensile strength is calculated through the following formula:
$F_{r}=\frac{P \times L \times 1000}{b h^{2}}$

Fr: modulus of rupture at MPa

$\mathrm{P}$ : the maximum load of the machine at $\mathrm{KN}$

L: distance between two supports of the specimen at $\mathrm{mm}$

B: width of the specimen at $\mathrm{mm}$

$\mathrm{h}$ : height of the specimen at $\mathrm{mm}$

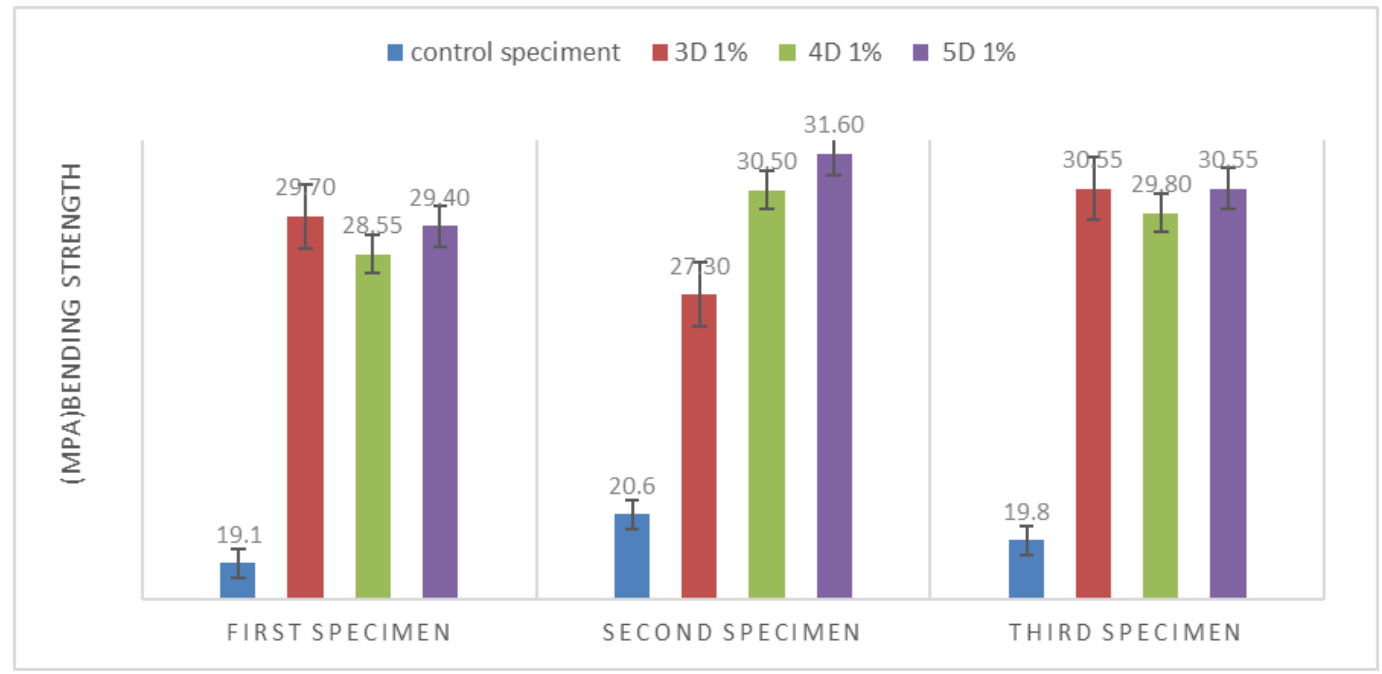

Fig. 8. The effect of steel fiber volume on 28- day bending strength of concrete reinforced with $1 \%$ fiber

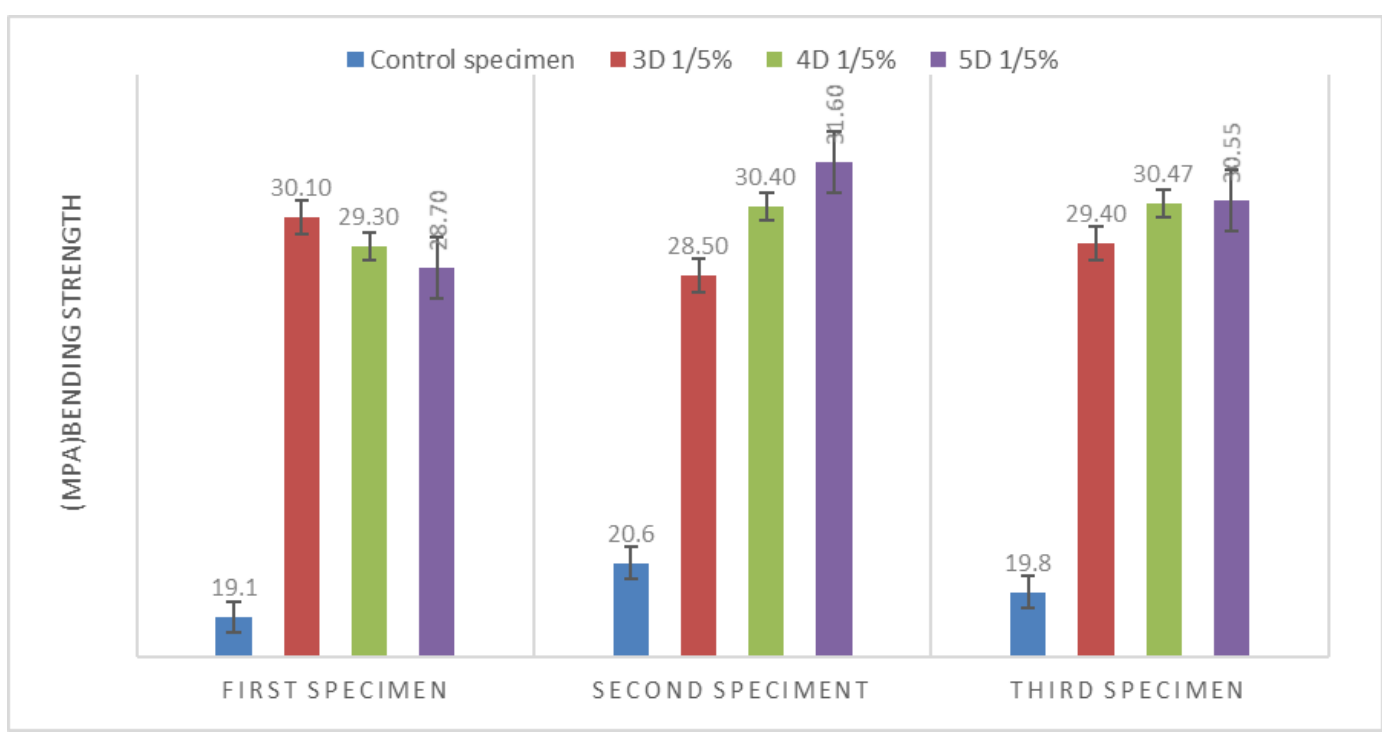

Fig. 9. the effect of steel fiber volume on 28- day bending strength of concrete reinforced with $1.5 \%$ fiber

According to Fig. 9, 28-day bending strength of plans of the mixture has somewhat been changed. In the condition, the used steel fiber increases the long-time bending strength of concrete in all specimens considerably. The highest 28-day bending strength is related to specimens reinforced with $2 \%$ steel fiber (3-D hooked steel fiber $\mathrm{L} / \mathrm{D}=$
80 and 5-D steel fiber $\mathrm{L} / \mathrm{D}=65$ ) with $31.7 \mathrm{MPa}$ and bending strength with $56.64 \%$ growth.

Fig. 9. shows that the lowest bending strength is related to specimens reinforced with $1 \%$ steel fiber (3-D hooked steel fiber L/D= 80) with 27.3 $\mathrm{MPa}$ and bending strength with $47.14 \%$ growth. 


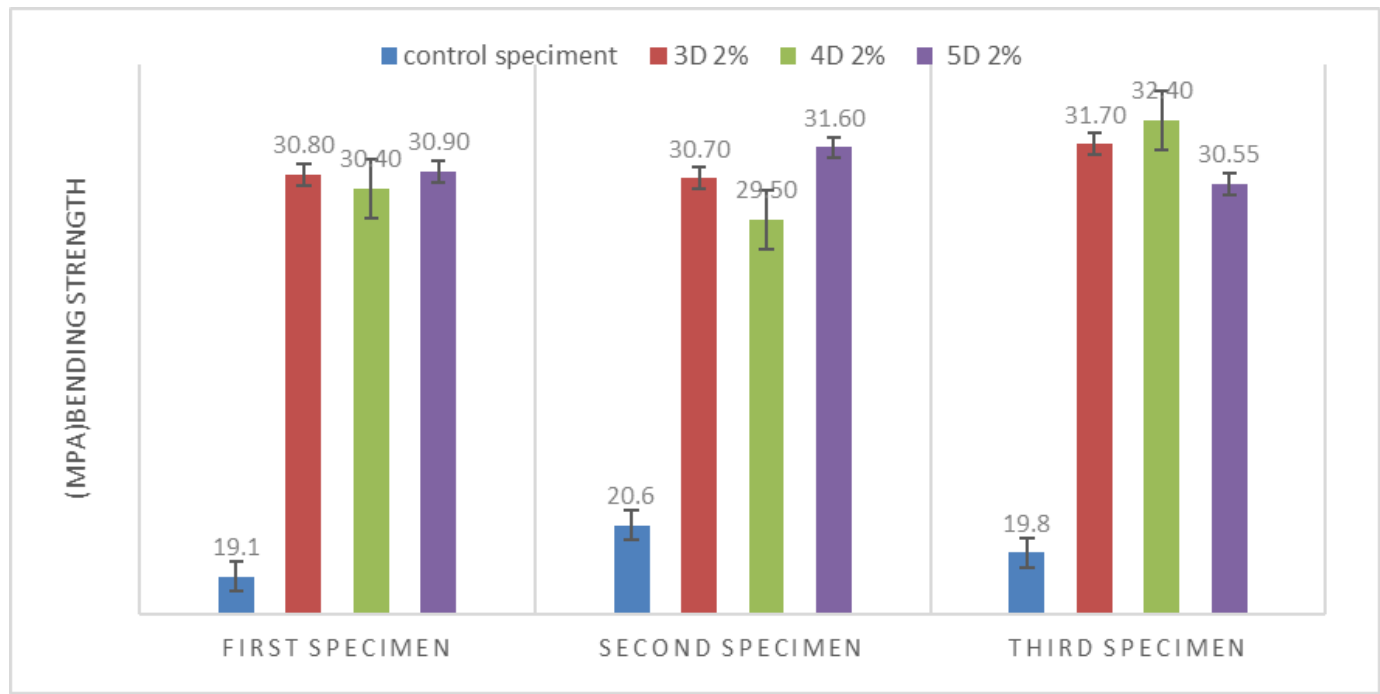

Fig. 10. the effect of steel fiber volume on 28-day bending strength of concrete reinforced with $2 \%$ fiber

As shown in Fig. 10, application of steel fibers has increased shortterm tensile strength of concrete in all cases. According to Fig. 6 , tensile strength of all samples has increased. Based on these results, the highest tensile strength exists in samples reinforced with 5D stee fibers (hooked steel fibers) with $56.39 \%$ tensile strength increase according to Fig 11 . The tensile toughness of concrete has significantly increased and concrete behavior become softer.

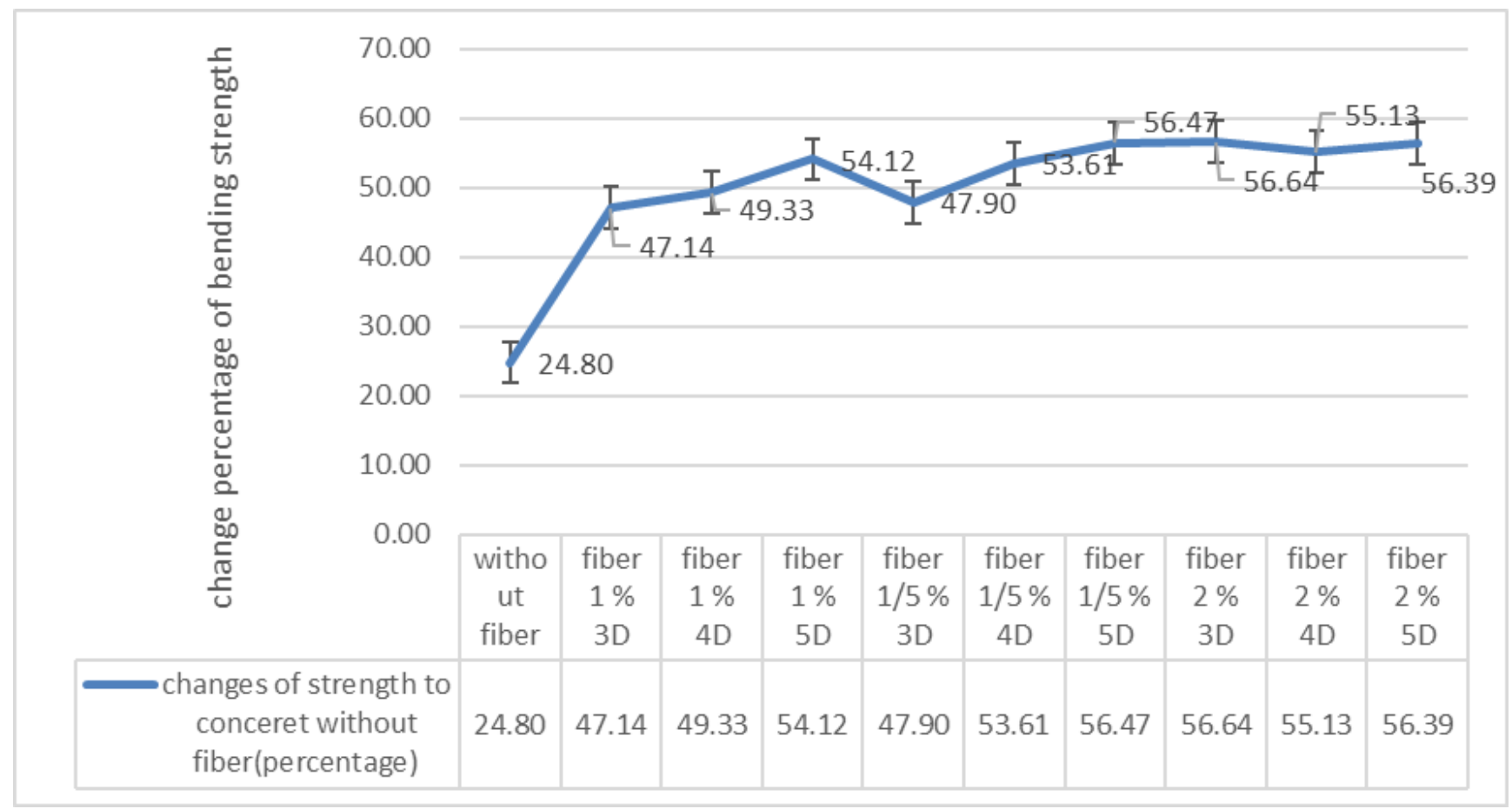

Fig. 11. The percentage graph of 28-day bending strength in steel fiber specimens to specimens without fiber

To examine tensile strength, the produced specimens have been tested after 28 days. 28-day tensile strength of control specimens related to the plan of mixture has been shown. Fig. 11-14 have indicated the final strength of the plans for specimens with different percentage of 28-day cylindrical hooked steel fiber volume $(1 \%, 1.5 \%$, and $2 \%$ ).
Generally, the results related to the effect of steel fiber on tensile strength can indicate as follows: Specimens reinforced with steel fiber show that the behavior of concrete under tensile is more ductility than specimens without fiber. According to the results, the fracture of specimens without steel fiber has been fragile. While steel fiberreinforced specimens have gradually been cracked. 


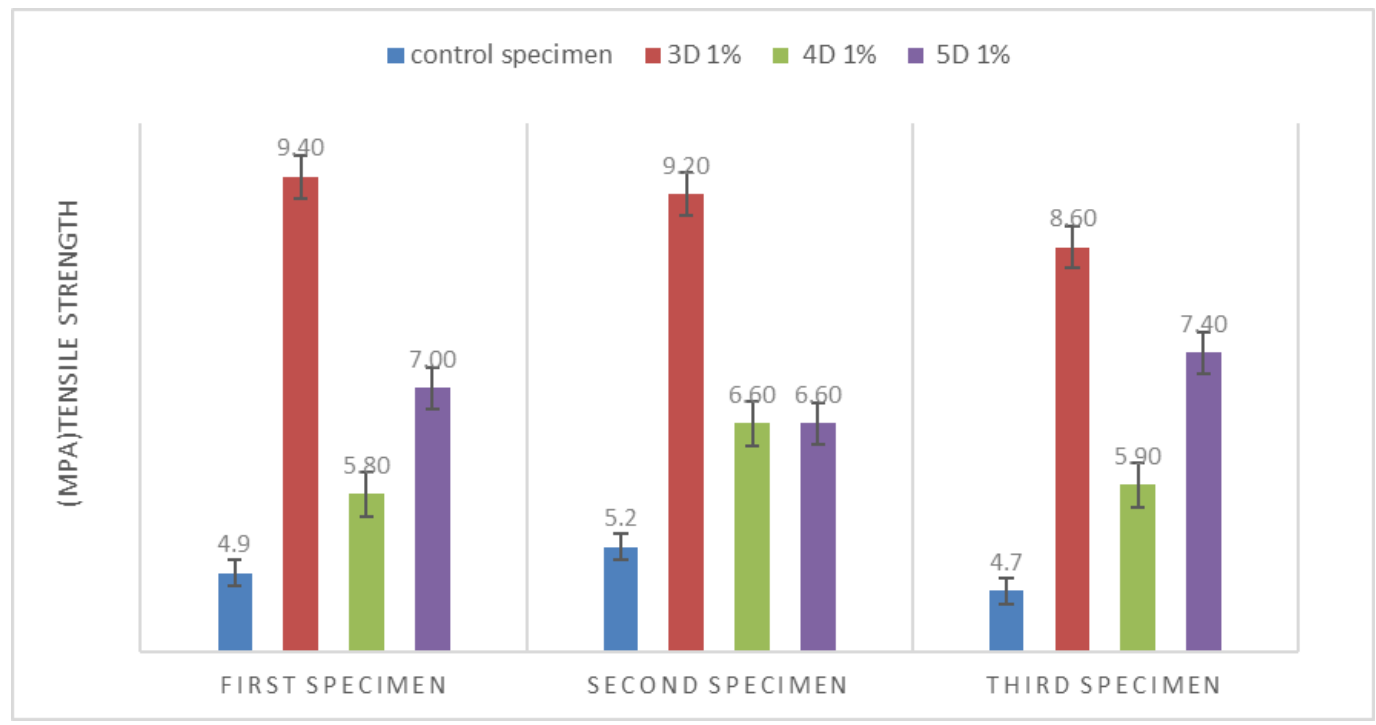

Fig. 12. the effect of steel fiber volume on 28-day tensile strength of concrete reinforced with $1 \%$ fiber

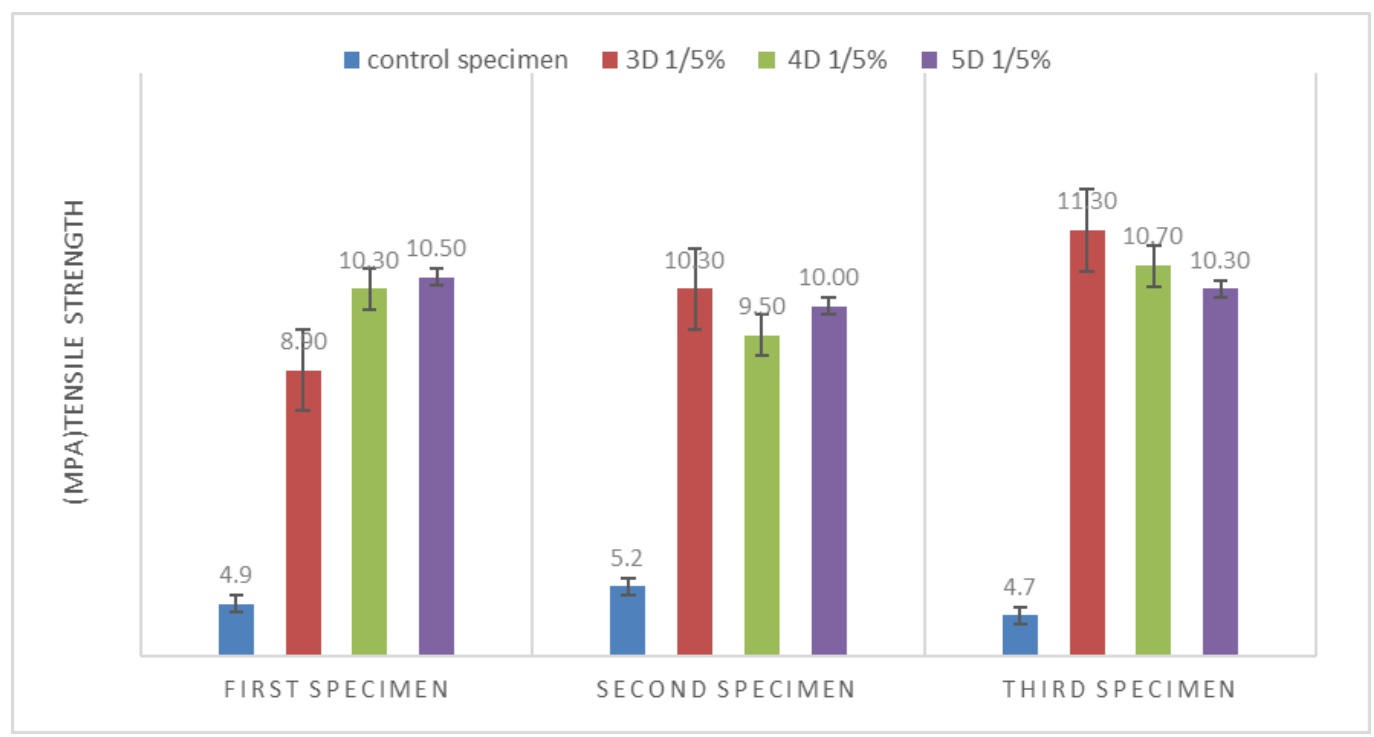

Fig. 13. the effect of steel fiber volume on 28-day tensile strength of concrete reinforced with $1.5 \%$ fiber

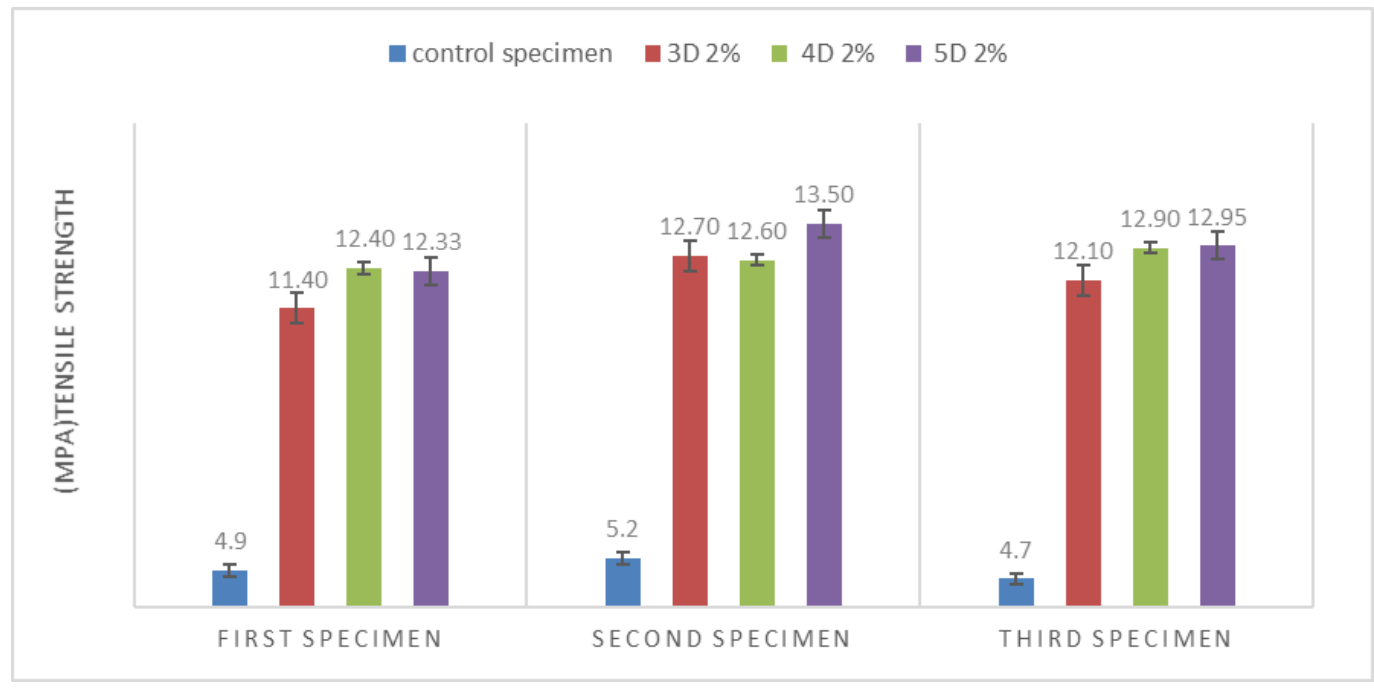

Fig. 14. the effect of steel fiber volume on 28 -day tensile strength of concrete reinforced with $2 \%$ fiber 
No-ruptured specimens and the available fiber have joined grains each other. The increased number of steel fiber enhances tensile strength of concrete considerably. The more the number of fiber is, the higher tensile strength of concrete becomes.

The lowest tensile strength is related to plans including Four-D hooked steel fiber (L/D =65). As shown in Fig. 10, 28-day tensile strength in the plans of mixture have mainly been changed.
According to Fig. 12, 28-day tensile strength have increased in all specimens. the results have demonstrated that the highest 28-day tensile strength is related to specimens reinforced with $2 \%$ Five-D steel fiber (hooked steel fiber $\mathrm{L} / \mathrm{D}=65$ ) with $135 \mathrm{MPa}$ and $162.03 \%$ growth of tensile strength.

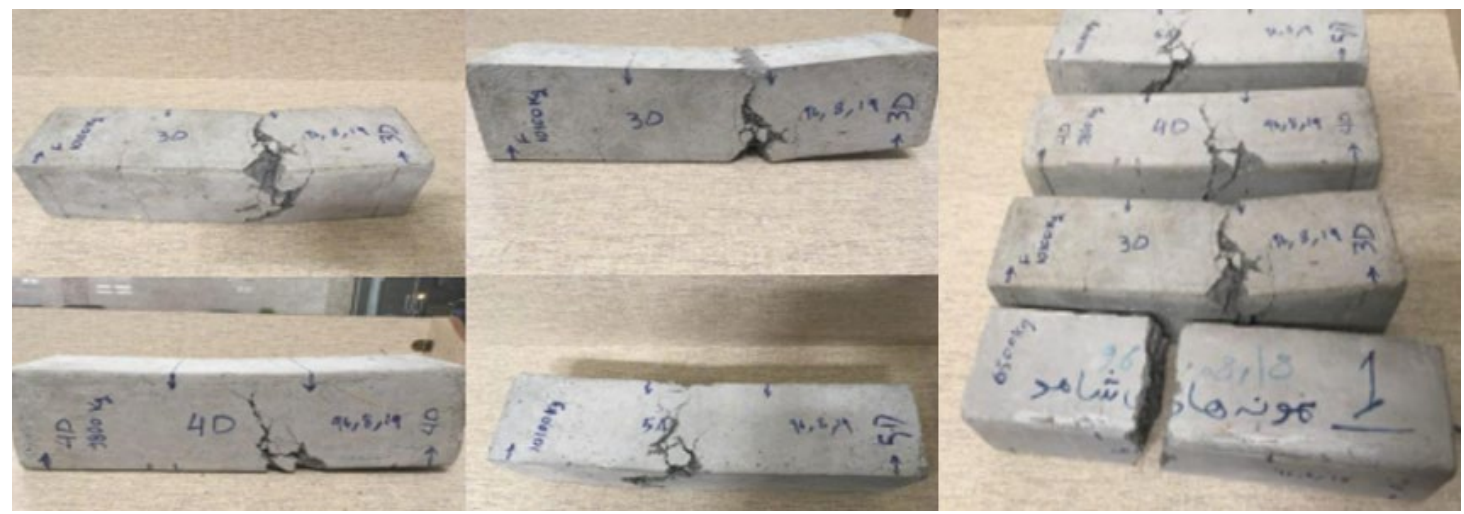

Fig.15. The cracking patterns

To survey cracking pattern of fig.6 tensile-matrix specimens reinforced with the different percentages of fiber, parameters such as the number of cracks, width of cracks and their distance from each other have been investigated. Cracking of the reinforced matrix specimen has presented that energy absorption of materials and their ductility are further when the number of cracks is more and they have the short distance from each other. The best cracking pattern in reinforced with cementitious composites is when cracking has been innumerous in very short distance. And demonstrates strainhardening behavior. When energy to make new crack is more than energy to open crack, matrix tends to innumerous cracking. The added different percentages of fibers change cracking pattern of material. If the percentage of fibers is enough and properties of matrix are suitable, the behavior of materials moves strain-softening into strain-hardening. Fig 15 has indicated cracking in specimens reinforced with $1 \%, 1.5 \%$ and $2 \%$ fibers. The cracking pattern is similar in specimens reinforced with 1 and 1.5 fibers and there are a min crack and some micro cracks around the pattern. Fracture of specimen follows the crack opening. as presented in the figure 15 , cracking pattern of specimens reinforced with $2 \%$ fiber has been in form of several close cracks (less than $1 \mathrm{~cm}$ in distance) and other micro cracks in far distance and finally ruptured specimens have been created through connection of small cracks. the added percentages of fiber improve the behavior of strength and energy absorption in the given movement after cracking of materials and causes ductility of materials. Also, emerging innumerous cracking and decreasing width of cracks, compared with growth of a crack and its more opening, help control width of cracks and improve strength of materials.

\section{CONCLUSION}

Tests of compressive, tensile, and bending strengths have concluded the following results in the study:

Steel fiber, even in high percentage, doesn't have a considerable effect on compressive strength but toughness strength is mainly increased in specimens and the behavior of concrete will be softer.

$>\quad$ The added steel fiber enhances tensile strength of concrete remarkably. The more the volume of fiber is, the more tensile strength of concrete is. The added steel fiber causes to enhance tensile toughness and softening behavior of concrete. The results of 28-day tensile strength indicate that the addition of steel fiber increases tensile strength linearly.

Fiber enhances bending strength of concrete considerably which is actually related to the volume of used fiber.

\section{Declaration of Conflict of Interests}

The author declares that there is no conflict of interest.

\section{References}

[1] Hannant, D. J., "Fiber Cements and Fiber Concrete", Wiley, Chi Chester, UK, 1987.

[2] Sahin, Y., Koksal, F., "The Influences of Matrix and Steel Fibre Tensile Strengths on the Fracture Energy of High-Strength Concrete", Construction and Building Materials, 2011, 25, 18011806.

[3] Yoon, Y. S., Yang, J. M., Lee, J. H., Lee, S. H., "Structural enhancement of High-Performance Concrete Members by Strategic Utilization of Steel fibers", The 9th International Symposium on High Performance Concrete - Design, Verification \& Utilization, Rotorua, New Zealand, 2011.

[4] Khaloo, A. R., Behavior and Applications of Fiber Concrete ", Proceedings of the First Conference on Fiber Concrete Technology, Sharif University of Technology, March 4, 1999, p. 30-1.

[5] Ünal, O., Demirbaş, F., Uygunoğlu, T., "Fuzzy Logic Approach to Predict Stress-Strain Curves of Fiber-Reinforced Concretes in Compression, Building and Environment", Building and Environment, Vol. 49, pp. 3589-3595, October 2006.

[6] Darwish, F. A., Oliveira, T. M., Coura, C. G., Kitamura, S., Barbosa, M. T. G., Santos, W., "Influence of Fiber Ratio in the Size Effect", Proceedings, Int'l Conference Concrete: Construction's sustainable option, Dundee, UK,2008, pp 123-130.

[7] Quresh L A et. al, (2008), "Effect of mixing steel fibers and silica fume on properties of high strength concrete", Proceedings. Int Conference Concrete: Constructions sustainable option, Dundee.UK, pp 173-185

[8] Kim D.J.and El-Tawil S. and Naaman A.E. (2010)"Correlation between Tensile and Bending Behavior of High Strength Deformed Steel Fibers" ACI Special Publication, Four Decades of Progress in Prestressed Concrete, Fiber Reinforced Concrete, and Thin Laminate Composites, pp 135-150, Para Montesinors, Balaguru.

[9] Vandewalle, L., "Hybrid Fiber Reinforced Concrete", Proceedings, Int'l Conference Concrete: Construction's Sustainable Option, Dundee, UK, 2008, pp 11-22.

[10] Pul S. (2008)"Experimental Investigation of Tensile Behavior of High Strength Concrete" Indian journal of engineering and material sciences, Vol 15, pp 467-472. 
[11] Xu B.W. and Shi H.S (2009)" Correlation among Mechanical properties of steel fiber reinforced composites" Journal construction and building materials, Vol 23, pp 3474-3468.

[12] Rodrigues, J. P., Laím, L., Correia, A. C., "Behavior of fiber reinforced concrete columns in fire, Composite Structures, Vol 92, pp 1263-1268, 2010.

[13] Nili, M. Afroughsabet, V," Combind effect of Silica Fume and Steel Fibers on the impact resistance and mechanical properties of concrete, International journal of impact engineering, (2010), 37,879-886.

[14] ASTM C78-10, "Standard Test Method for Flexural Strength of Concrete (Using Simple Beam with Third-Point Loading)", ASTM International, USA, 2010.

[15] Kurt M, Kotan, T., Gül, M.S., Gül, R., Aydin, A.C., The Effect of Blast Furnace Slag to Self-Compactability of Pumice Aggregate Lightweight Concrete, SADHANA Academy Proceedings in Engineering Sciences, 41(2), February 2016, pp.253-264.

[16] Aydın, A.C., Karakoç, M.B., Düzgün, O.A., and Bayraktutan, M.S., Effect of low quality aggregates on the mechanical properties of lightweight concrete, Scientific Research and Essays Vol. 5 (10), pp. 1133-1140, 18 May, 2010.

[17] Kurt M, Aydin, A.C., Gül, M.S., Gül, R., Kotan, T., The Effect Of Fly Ash To Self-Compactibility Of Pumice Aggregate Lightweight Concrete, SADHANA Academy Proceedings in Engineering Sciences, Vol. 40, Part 4, June 2015, pp. 1343-1359.

[18] Aydın, A.C., Self Compactability of High-Volume Hybrid Fiber Reinforced Concrete, Construction and Building Materials, 21, 1146-1151, (2007).

\section{How to Cite This Article}

Fard, S.G., Hybrid Fiber Reinforced Concrete with Pozzolanic Materials, Cement Based Compoasites, 1(2020), 16-24. https://doi.org/10.36937/cebacom.2020.001.004 